\title{
PENGEMBANGAN MEDIA PEMBELAJARAN INTERAKTIF IPS BERBASIS PROBLEM BASED LEARNING DAN ULAR TANGGA
}

\author{
Dita Priska Pravita Sari ${ }^{1}$, Murtono ${ }^{2}$, Slamet Utomo ${ }^{3}$ \\ 1,2,3 Magister Pendidikan Dasar, Universitas Muria Kudus \\ 1email : priskadita90@gmail.com \\ 2email : murtono@umk.ac.id \\ 3email : slamet.utomo@umk.ac.id
}

\begin{abstract}
This study aims to (1) developing interactive learning media based on Problem Based Learning and snakes and ladders for fourth grade social studies, (2) describe the feasibility of interactive learning media based on Problem Based Learning and snakes and ladders for fourth grade social studies This study uses Borg and Gall development, namely (1) information gathering, (2) initial product development, (3) expert evaluation, (4) product testing, (5) product revision, (6) product testing, (7) final product. This interactive learning media products are packaged on CD or soft files with a guidebook. This interactive learning media can be played on computers, laptops, and Android smartphone. Interactive learning media based on problem-based learning and snakes and ladders proved to be very feasible by seeing the results of the material expert's validation, media expert validation, linguist validation, and field practitioner validation respectively $97.50 \%, 96.67 \%, 92.50 \%$, and $77.86 \%$ with an average percentage of eligibility reaching 91.13\%. Product feasibility is also seen based on the results of field trials which show teacher responses and student responses respectively $89.28 \%$ and $81.06 \%$ with an average percentage of $85.17 \%$. This interactive learning media is suitable for use in the fourth grade social studies.
\end{abstract}

Keywords: Problem Based Learning, Snake and Ladder Games

\begin{abstract}
Abstrak: Penelitian ini bertujuan untuk (1) mengembangkan media pembelajaran interaktif berbasis Problem Based Learning dan ular tangga pelajaran IPS Kelas IV SD, dan (2) mendeskripsikan kelayakan media pembelajaran interaktif berbasis Problem Based Learning dan ular tangga pelajaran IPS Kelas IV SD. Penelitian ini menggunakan desain pengembangan menurut Borg and Gall yakni (1) pengumpulan informasi, (2) pengembangan produk awal, (3) evaluasi ahli, (4) uji coba produk, (5) revisi produk, (6) uji coba produk, (7) produk akhir. Penelitian dan pengembangan ini menghasilkan produk media pembelajaran interaktif yang dikemas dalam bentuk CD atau soft file dilengkapi dengan buku panduan penggunaan. Media pembelajaran interaktif ini bisa dimainkan di komputer, laptop, dan smartphone Android. Media pembelajaran interaktif berbasis Problem Based Learning dan permainan ular tanggaterbukti sangat layak digunakan dengan melihat hasil validasi ahli materi, validasi ahli media, validasi ahli bahasa, dan validati praktisi lapangan berturut-turut 97,50 \%, 96,67 \%, 92,50 \%, dan $77,86 \%$ dengan rata-rata persentase kelayakan mencapai 91,13\%. Kelayakan produk juga dilihat berdasarkan hasil ujicoba lapangan yang menunjukkan respon guru dan respon siswa berturut-turut 89,28\% dan 81,06 \% dengan rata-rata persentase sebesar $85,17 \%$. Media pembelajaran interaktif ini layak digunakan pada mata pelajaran IPS kelas IV SD.
\end{abstract}

Kata kunci: Problem Based Learning, Permainan Ular Tangga 


\section{PENDAHULUAN}

Pembelajaran IPS selama ini identik dengan hafalan karena memiliki banyak materi. Dalam pelaksanaan pembelajarannya, guru masih menggunakan model konvensional. Akibatnya materi-materi tersebut sulit dipahami oleh siswa sehingga pembelajaran IPS menjadi membosankan dan tidak menarik bagi siswa.

Sapriya (2009: 12) mengemukakan bahwa pendidikan IPS di tingkat sekolah pada dasarnya bertujuan untuk mempersiapkan para peserta didik sebagai warga negara yang menguasai pengetahuan (knowledge), keterampilan (skill), sikap dan nilai (attitudes and values) yang dapat digunakan sebagai kemampuan untuk memecahkan masalah pribadi atau masalah sosial serta kemampuan mengambil keputusan dan berpartisipasi dalam berbagai kegiatan masyarakat agar menjadi warga negara yang baik. Oleh karena itu, guru sebagai fasilitator idealnya memiliki kemampuan dalam menciptakan pembelajaran yang efektif sesuai dengan karakteristik peserta didik, materi pelajaran serta lingkungan belajar untuk meningkatkan kompetensi peserta didik.

Pernyataan tersebut sejalan dengan pendapat Ramadhani (2015: 35-36) yang berpendapat bahwa guru dituntut untuk menciptakan proses pembelajaran yang efektif dan inovatif diantaranya adalah penggunaan model dan media pembelajaran yang dilakukan seefektif mungkin dalam suasana yang menyenangkan dan bermakna.

Penerapan model pembelajaran yang variatif dapat didukung dengan penggunaan media pembelajaran yang akan membantu guru dalam menyampaikan materi kepada siswa. Terutama pada siswa sekolah dasar yang tahapan berpikirnya masih berada pada tahap operasional konkret sehingga dibutuhkan media pembelajaran untuk membantu siswa dalam memahami konsep materi pelajaran. Penggunaan media pembelajaran juga akan menciptakan lingkungan belajar yang menyenangkan sehingga dapat meningkatkan motivasi siswa untuk belajar dan aktif dalam pembelajaran.

Pernyataan ini diperkuat dengan pendapat Pangestu (2018:8) yang menyatakan penggunaan media dalam proses pembelajaran dapat membantu siswa untuk memperoleh pemahaman yang lebih baik, menyajikan data yang menarik dan terpercaya, memudahkan penafsiran data, dan memadatkan informasi. Siswa yang belajar dengan menggunakan media pembelajaran akan cenderung lebih tertarik untuk belajar dibandingkan siswa yang hanya belajar dengan cara mendengarkan penjelasan guru.

Pada bulan maret 2020, dunia sedang menghadapi pandemi covid-19 tak terkecuali dengan Indonesia. Pandemi covid-19 ini berdampak pada dunia pendidikan. Selama pandemic covid-19 pembelajaran tidak dapat dilakukan secara tatap muka melainkan harus dilakukan secara daring. Pembelajaran secara daring merupakan hal baru dalam pendidikan dan memberikan tantangan baru bagi dunia pendidikan.

Dalam pembelajaran daring guru dan siswa tidak dapat berinteraksi secara langsung. Dibutuhkan media sebagai perantara untuk menghubungkan terjalinnya interaksi antara guru dan siswa. Oleh karena itu, media pembelajaran sangat dibutuhkan untuk membantu dan memfasilitasi siswa dalam proses pembelajaran daring. Sebagaimana pendapat yang disampaikan Huda (2013: 100) bahwa media pembelajaran berfungsi secara efektif dalam proses pembelajaran yang berlangsung tanpa menuntut kehadiran guru. 
Media pembelajaran hendaknya tidak bersifat linier saja yang hanya dilihat ataupun didengar oleh siswa. Akan tetapi, dapat membangun interaksi dengan siswa untuk belajar. Apalagi dalam kondisi pandemi covid-19 saat ini, pembelajaran harus dapat dilakukan dimana saja dan kapan saja. Oleh karena itu, guru dituntut untuk berinovasi dengan memanfaatkan perkembangan teknologi dalam melaksanakan pembelajaran. Alternatif cara yang dapat dilakukan adalah dengan mengembangkan media pembelajaran interaktif.

Alternatif pemecahan masalah tersebut diperkuat dengan pendapat Istianah (2020: 114-115) yang menyatakan bahwa multimedia pembelajaran interaktif menggunakan powerpoint merupakan salah satu media pembelajaran yang memanfaatkan teknologi informasi dan komunikasi yang dapat dapat memotivasi siswa dalam belajar.

Tarigan dan Siagian (2015: 198) juga mengungkapkan bahwa, "terdapat perbedaan yang signifikan antara hasil belajar siswa yang dibelajarkan dengan menggunakan media pembelajaran interaktif." Pernyataan tersebut menunjukkan bahwa media pembelajaran interaktif memberikan efek positif terhadap pembelajaran siswa.

Namun, media pembelajaran interaktif yang baik tidak hanya berisi materi saja, melainkan dapat berisi hal-hal yang dapat membantu proses analisis siswa serta mengembangkan keterampilan berpikir siswa. Keterampilan berpikir dapat dikembangkan melalui kegiatan mengamati, mencoba, menalar, berkomunikasi serta menyimpulkan. Kegiatan tersebut terdapat dalam model problem based learning. Oleh karena itu, materi pembelajaran dalam pengembangan media pembelajaran interaktif ini dibuat dengan memuat langkah-langkah dari model problem based learning (PBL).

Sani (2018: 157) mengemukakan pembelajaran berbasis masalah yang dikembangkan sebagai model pembelajaran memiliki sintaks belajar sebagai berikut :

1. Memberikan orientasi permasalahan kepada peserta didik. Guru menyajikan permasalahan, membahas tujuan pembelajaran, dan memaparkan kebutuhan logistic untuk pembelajaran.

2. Mengorganisasikan peserta didik untuk penyelidikan. Guru membantu peserta didik untuk mendefinisikan dan mengorganisasikan tugas belajar/penyelidikan untuk menyelesaikan permasalah.

3. Pelaksanaan investigasi. Guru mendorong peserta didik untuk memperoleh informasi yang tepat, melaksanakan penyelidikan, dan mencari penjelasan solusi.

4. Mengembangkan dan menyajikan hasil. Guru membantu peserta didik untuk merencanakan produk yang tepat dan relevan, seperti laporan, rekaman video, dan sebagainya untuk keperluan penyampaian hasil.

5. Menganalisis dan mengevaluasi proses penyelidikan. Guru membantu peserta didik melakukan refleksi terhadap penyelidikan dan proses yang mereka lakukan.

Pembelajaran dalam PBL disampaikan melalui permasalahan dalam kehidupan nyata yang harus ditemukan pemecahan permasalahannya oleh siswa. Dengan demikian, pengetahuan dan keterampilan yang diperoleh siswa dalam pembelajaran dapat ia aplikasikan dalam kehidupan sehari-hari. Pembelajaran yang dilakukan siswa lebih bermakna karena konsep-konsep yang ia temukan dapat digunakan untuk memecahkan masalah. Hal ini didukung pendapat dari Henk Huijser, et al (2015: 308), "in PBL, students habitually seek, analyse, synthesise and apply information, with the guidance of the teacher, to resolve the 
problems presented to them at the outset." Dalam PBL, siswa akan terbiasa mencari, menganalisis, mensintesis, dan menerapkan informasi untuk menyelesaikan masalah yang disajikan oleh guru sejak awal pembelajaran. Guru dapat menggunakan masalah-masalah autentik yang dapat meningkatkan minat dan motivasi siswa untuk belajar dari proses pemecahan masalah.

Penelitian mengenai pengembangan media pembelajaran interaktif dalam problem based learning telah dilakukan oleh peneliti terdahulu, yakni Anggraeni (2017) yang menunjukkan bahwa media pembelajaran interaktif berbasis model PBL layak digunakan dan dapat membantu siswa untuk belajar secara aktif dan mandiri. Hasil penelitian Khamzawi, et al (2015) menunjukkan bahwa multimedia interaktif berbasis model pembelajaran Problem Based Learning (PBL) pada mata pelajaran fisika pokok bahasan fluida dinamis memiliki kevalidan dan kepraktisan dengan kategori sangat valid dan sangat praktis. Selain itu, juga memberikan efek yang baik terhadap hasil belajar siswa.

Media pembelajaran interaktif yang akan dikembangkan dalam penelitian ini tidak sekedar berisi materi dengan menerapkan langkah-langkah PBL. Akan tetapi, dilengkapi pula dengan soal yang dapat digunakan sebagai penilaian formatif. Agar lebih menarik, maka dalam media ini ditambahkan dengan permainan yang menantang siswa untuk belajar. Pentingnya permainan dalam pembelajaran sekolah dasar ditegaskan oleh Veličković (2013) yang berpendapat bahwa "... we think is a significant possibility of using games in educational work with children in the elementary grades, and how to help your child through the game more quickly and more easily overcome the problems of adaptation to the school environment and learning".
Peneliti memilih menggunakan permainan ular tangga dalam media pembelajaran interaktif ini karena permainan ular tangga merupakan permainan yang sudah dikenal oleh siswa dan dapat digunakan dalam pembelajaran.Tegeh dan Budiartini (2017: 138) berpendapat bahwa permainan ular tangga dapat digunakan pada semua mata pelajaran serta dapat meningkatkan interaksi siswa selama proses pembelajaran.

Penelitian mengenai pengembangan permainan ular tangga sebelumnya pernah dilakukan oleh Budiman, et al (2017) menunjukkan bahwa pengembangan aplikasi game interaktif ular tangga dapat membantu anak-anak mempelajari matematika dasar dengan cara mengisi soal-soal yang ada dalam game interaktif.

Pandangan pembelajaran IPS yang membosankan dapat dirubah menjadi pembelajaran yang menyenangkan dengan mengembangkan media pembelajaran interaktif berbasis Problem Based Learning dan permainan ular tanggasehingga siswa akan lebih tertarik untuk belajar IPS. Selain itu, media ini juga memberikan kesempatan bagi siswa untuk terampil memecahkan permasalahan dalam kehidupan, mencari solusi permasalahan, serta melatih kemandirian, kejujuran dan tanggung jawab siswa.

Berdasarkan paparan di atas, penulis tertarik untuk melaksanakan penelitian dengan judul Pengembangan Media Pembelajaran Interaktif berbasis Problem Based Learning dan permainan ular tangga Mata Pelajaran IPS Kelas IV SD. Rumusan permasalahan dalam penelitian ini adalah 1) bagaimana Pengembangan Media Pembelajaran Interaktif berbasis Problem Based Learning dan permainan ular tangga Mata Pelajaran IPS Kelas IV SD. 2) bagaimana kelayakan media pembelajaran interaktif berbasis Problem Based Learning dan permainan ular tangga mata pelajaran IPS Kelas IV SD. 
Sesuai dengan rumusan masalah di atas, maka tujuan penelitian ini adalah 1) Mendeskripsikan Pengembangan Media Pembelajaran Interaktif berbasis Problem Based Learning dan Permainan Ular Tangga Mata Pelajaran IPS Kelas IV SD, 2) Mendeskripsikan kelayakan media pembelajaran interaktif berbasis Problem Based Learning dan permainan ular tangga mata pelajaran IPS Kelas IV SD.

\section{METODE PENELITIAN}

Penelitian ini merupakan penelitian pengembangan atau Research \& Development (R\&D). Penelitian ini menghasilkan produk berupa media pembelajaran interaktif yang dibuat menggunakan software bawaan dari Microsoft Office yaitu Microsoft Office Power Point. Media pembelajaran yang dihasilkan dapat digunakan di Komputer, laptop, dan HP Android. Desain dalam penelitian ini mengacu pada desain pengembangan dari Borg and Gall. Desain pengembangan dari Borg and Gall ini terdiri dari sepuluh tahapan. Namun, dalam penelitian dan pengembangan ini disederhanakan menjadi tujuh tahapan, yakni (1) pengumpulan informasi, (2) pengembangan produk awal, (3) evaluasi ahli, (4) uji coba produk, (5) revisi produk, (6) uji coba produk, (7) produk akhir.

Subyek dalam penelitian ini terdiri dari subyek ahli yakni dosen Universitas Muria Kudus sebagai ahli materi pembelajaran, ahli media pembelajaran, dan ahli bahasa serta satu guru kelas IV SD sebagai praktisi lapangan. Sedangkan subyek ujicoba yakni guru dan siswa kelas IV di lima sekolah dasar yang berada di Kecamatan Jati Kabupaten Kudus.

Teknik pengumpulan data dalam penelitian ini diperoleh melalui wawancara, angket dan dokumentasi. Validasi media pembelajaran dilakukan dengan meminta pendapat para ahli (expert judment) yakni pendapat dari dosen Universitas Muria Kudus dan Guru Kelas IV Sekolah Dasar melalui angket. Kelayakan produk diuji cobakan dalam uji coba terbatas yang melibatkan 1 sekolah dasar dan ujicoba skala luas pada 5 sekolah dasar di Kecamatan Jati Kabupaten Kudus.

Teknik analisis dalam penelitian ini menggunakan teknik deskriptif kualitatif dan kuantitatif. Hasil masukan dari para ahli mengenai pengembangan produk diolah menggunakan analisis deskriptif kualitatif. Hasil penilaian kelayakan media pembelajaran diolah menggunakan analisis deskriptif kuantitatif untuk memperoleh tingkat pencapaian validasi produk. Uji kelayakan pada media pembelajaran interaktif dilakukan dengan membandingkan jumlah skor ideal yang diperoleh pada angket respon guru dan siswa ( R) dengan jumlah skor maksimal yang telah ditetapkan di dalam angket. Pengembangan media pembelajaran interaktif berbasis Problem Based Learning dan Permainan Ular Tangga dinilai layak apabila memperoleh skor persentase $\geq 61 \%$.

\section{HASIL DAN PEMBAHASAN}

Berdasarkan tahapan penelitian dan pengembangan yang dilakukan oleh peneliti, diperoleh produk pengembangan berupa media pembelajaran interaktif berbasis Problem Based Learning dan Permainan Ular Tangga untuk mata pelajaran IPS Kelas IV SD Tema Indahnya Keragaman Negeriku. Produk yang dihasilkan oleh peneliti dikembangkan berdasarkan tahapan penelitian dan pengembangan yang 
dikemukakan oleh Borg \& Gall. Namun, karena keterbatasan biaya dan waktu yang dimiliki oleh peneliti, maka langkahlangkah penelitian dan pengembangan produk dari Borg \& Gall disederhanakan hanya sampai 7 langkah saja

Pada tahap awal, peneliti melakukan studi pustaka, wawancara dan observasi guna mengidentifikasi potensi dan permasalahan pembelajaran di lapangan yang dijadikan sebagai dasar melakukan penelitian dan pengembangan ini. Studi pustaka yang dilakukan untuk mengetahui teori-teori, konsep, kajian tentang model pengembangan media pembelajaran interaktif yang baik serta kompetensi inti, kompetensi dasar, dan materi pembelajaran IPS.

Sementara itu wawancara juga dilakukan untuk mengetahui permasalahan yang ada dalam pembelajaran IPS. Dari hasil wawancara dengan guru di SD 1 Ngembal Kulon diketahui bahwa sebenarnya semua materi pembelajaran IPS sudah disampaikan kepada siswa tetapi siswa kurang berminat pada pembelajaran IPS karena siswa merasa sulit untuk memahami materi yang diajarkan. Siswa menganggap IPS terlalu banyak materinya, buku-bukunya terlalu tebal dan bahasanya sulit dimengerti oleh siswa. Di sisi lain, guru mengalami kesulitan dalam berinovasi dalam kegiatan pembelajaran terutama untuk membuat media pembelajaran karena keterbatasan waktu dan tenaga. Pada akhirnya guru hanya menggunakan buku paket yang ada dan gambar-gambar dalam pembelajaran.

Sedangkan observasi dilakukan dengan tujuan menganalisis kebutuhan pembelajaran dan mengetahui kondisi pembelajaran yang berlangsung selama ini dan selama pembelajaran jarak jauh pada masa pandemi Covid-19. Hasil observasi menunjukkan pembelajaran selama ini monoton dan membosankan. Media pembelajaran jarang sekali digunakan saat pembelajaran IPS. Sedangkan pembelajaran daring selama pandemic covid-19 ini didominasi dengan metode penugasan yang membuat siswa jenuh dan tidak semangat dal;am belajar. Oleh karena itu, diperlukan suatu media pembelajaran interaktif agar pembelajaran tidak monoton dan membosankan serta dapat memotivasi siswa untuk belajar.

Pengembangan produk awal dimulai dengan perencanaan pengembangan media pembelajaran yang bisa digunakan secara fleksibel menyesuaikan kondisi dan situasi yang sedang berkembang saat ini yaitu bisa digunakan dalam pembelajaran jarak jauh maupun secara tatap muka. Peneliti memutuskan untuk mengembangkan media pembelajaran interaktif berbasis PBL Kemudian menentukan format media pembelajaran interaktif yang akan dibuat berupa powerpoint. Setelah itu menyusun alur cerita atau storyboard yang memberi gambaran garis besar isi media pembelajaran, mengumpulkan bahan yang terdiri dari teks, gambar, video, audio dan animasi yang sesuai dengan materi pembelajaran IPS serta menarik bagi siswa. Adapun produk yang dihasilkan dari penelitian ini adalah produk berupa media pembelajaran interaktif berbasis Problem Based Learning dan Permainan Ular Tangga yang dibuat menggunakan program Microsoft powerpoint yang dikemas dalam bentuk CD atau soft file dilengkapi dengan buku panduan penggunaan.

Media pembelajaran interaktif berbasis PBL dan permainan ular tangga ini bisa dimainkan di laptop, PC dan HP Android. Untuk penggunaan aplikasi di 
HP Android, siswa diharuskan menginstal aplikasi pendamping yaitu WPS Office. Ekstensi file dari aplikasi media pembelajaran interaktif berbasis PBL dan permainan ular tangga ini berupa pptx. Agar dapat digunakan secara interaktif maka file aplikasi media pembelajaran interaktif diputar dalam mode Slide Show.

Adapun bagian-bagian dari media pembelajaran ini terdiri dari halaman awal yang berisi video pengantar pembelajaran sebelum pengguna dibawa ke menu pembelajaran. Halaman menu utama berisi menu-menu yang terdapat dalam aplikasi pembelajaran. Halaman ini disertai narasi singkat berupa audio suara.

Menu petunjuk berisi petunjuk singkat penggunaan aplikasi baik bagi guru maupun siswa. Menu petunjuk ini bisa digeser ke kiri dan ke kanan menggunakan tanda panah sesuai kebutuhan pengguna. Menu KI dan KD berisi uraian kompetensi inti dan kompetensi dasar beserta tujuan pembelajaran yang harus dicapai oleh siswa. Menu Pembelajaran berisi materi dan proses pembelajaran yang dibagi dalam tiga subtema. Proses pembelajaran di setiap subtema mengikuti alur model pembelajaran PBL terdiri dari orientasi masalah, organisasi peserta didik, investigasi kelompok/individual, menyajikan hasil investigasi dan analisi serta evaluasi proses. Menu permainan berisi permainan ular tangga yang terdiri dari sepuluh soal sesuai dengan tema pembelajaran. Bentuk soal berupa pilihan ganda, jika benar maka siswa akan di bawa ke soal selanjutnya menaiki tangga, jika salah siswa akan tetap berada di posisi awal atau turun ke posisi semula. Menu profil berisi biodata pengembang aplikasi media pembelajaran interaktif berbasis PBL dan permainan ular tangga. Menu keluar untuk keluar dari aplikasi. Aplikasi tidak akan menutup selama siswa selaku pengguna tidak memilih atau menekan tombol silang (exit) pada pilihan menu keluar.

Sementara itu, sintaks model pembelajaran PBL yang diintegrasikan dalam media pembelajaran interaktif berbasis PBL dan permainan ular tangga pada penelitian ini diuraikan sebagai berikut :

a. Ayo amati, tahapan ini merupakan aplikasi dari tahap orientasi masalah dimana pada bagian ini memaparkan mengenai kebutuhan yang akan dipelajari seta menyajikan permasalahan yang berkaitan dengan kehidupan nyata.

b. Ayo berpikir, tahapan ini merupakan aplikasi dari tahap mengorganisasikan siswa untuk belajar. Pada bagian ini disajikan pengorganisasian tugas belajar yang harus dilakukan siswa sesuai permasalahan yang telah disajikan.

c. Ayo membaca, tahapan ini merupakan aplikasi dari tahapan pelaksanaan investigasi, dimana pada bagian ini siswa didorong untuk menemukan informasi yang tepat sebagai solusi dari pemecahan masalah.

d. Ayo berkarya, tahapan ini merupakan aplikasi dari tahap menyajikan hasil karya. Pada bagian ini, siswa dibantu agar dapat menyajikan solusi pemecahan masalahnya dalam bentuk tabel.

e. Ayo kaji ulang, tahapan ini merupakan aplikasi dari tahap analisis dan refleksi proses penyelidikan siswa dalam menemukan pemecahan masalah. Pada bagian ini, siswa 
diminta untuk merefleksi pemecahan masalah yang telah ditemukan.

Selain mengintegrasikan PBL dalam media pembelajaran interaktif, peneliti juga mengaplikasikan permainan sederhana dalam media tersebut. Permainan dalam kegiatan pembelajaran memiliki manfaat yang baik bagi peserta didik karena dengan permainan peserta didik tidak jenuh mengikuti pembelajaran yang berlangsung, membuat situasi pembelajaran menjadi menyenangkan, memudahkan siswa untuk belajar, melatih konsentrasi, kreativitas serta imajinasi peserta didik.Permainan yang disisipkan berupa kuis dan latihan soal dimana cara mengerjakannya mengadopsi langkahlangkah permainan pada permainan ular tangga. Pada penelitian ini, bentuk permainan ular tangga divisualisasikan oleh seorang tokoh bernama Budi yang menaiki tangga dengan aturan jika dapat menjawab benar maka dapat menaiki tangga. Namun, jika jawabannya salah, maka harus menuruni tangga.
Produk awal Pengembangan media pembelajaran interaktif berbasis Problem Based Learning dan Permainan Ular Tangga yang sudah selesai didesain selanjutnya di evaluasi dan divalidasi oleh ahli.

Evaluasi produk oleh ahli dilakukan oleh ahli bidang pendidikan, yaitu dosen PGSD Universitas Muria Kudus. Evaluasi ahli dilakukan untuk mengevaluasi kelayakan media pembelajaran. Hasil evaluasi dari para ahli dianalisis kemudian dilakukan perbaikan terhadap produk agar mendapatkan produk media pembelajaran interaktif yang baik dan dapat di uji cobakan

Berdasarkan hasil yang diperoleh pada tahap pengembangan yaitu penilaian ahli dan uji coba, produk media pembelajaran interaktif yang dihasilkan telah mencapai kriteria pengembangan produk yang telah ditetapkan. Hal ini dapat dilihat dari hasil penilaian ahli sebagai berikut.

Tabel 1. Hasil Penilaan Ahli Terhadap Kelayakan Produk

\begin{tabular}{clcc} 
No & \multicolumn{1}{c}{ Jenis Validasi } & Persentase & Kelayakan \\
\hline 1 & Validasi Ahli Materi & $97,50 \%$ & Sangat layak \\
\hline 2 & Validasi Ahli Media & $96,67 \%$ & Sangat layak \\
\hline 3 & Validasi Ahli Bahasa & $92,50 \%$ & Sangat layak \\
\hline 4 & $\begin{array}{l}\text { Validasi Praktisi } \\
\text { Lapangan }\end{array}$ & $77,86 \%$ & Layak \\
\hline & Rata-rata & $91,13 \%$ & Sangat layak
\end{tabular}

Tabel 2. Hasil Ujicoba Lapangan Terhadap Kelayakan Produk

\begin{tabular}{clcc} 
No & Jenis Ujicoba & Persentase & Kelayakan \\
\hline 1 & Respon Guru & $89,28 \%$ & Sangat layak \\
\hline 2 & Respon Siswa & $81,06 \%$ & Sangat layak \\
\hline & Rata-rata & $85,17 \%$ & Sangat layak
\end{tabular}

Dari hasil penilaian ahli terhadap kelayakan produk diketahui bahwa produk media pembelajaran interaktif berbasis PBL dan permainan ular tangga sangat layak untuk diujicobakan dengan skor persentase sebesar 95,56\%. Hasil penilaian ahli tersebut didukung oleh hasil ujicoba lapangan pada tabel 2. 
Berdasarkan tabel 2, diketahui bahwa respon guru menunjukkan skor $89,28 \%$ dengan kategori sangat layak. Sedangkan respon siswa menunjukkan skor sebesar $81.06 \%$ dengan kategori sangat layak. Secara umum, skor persentasi respon siswa dan guru terhadap pengembangan media mencapai persentase $85,17 \%$. Dengan demikian produk sangat layak dan siap digunakan untuk skala yang lebih luas, misalnya dalam satu kecamatan atau bahkan satu kabupaten.

Hasil dalam penelitian ini memiliki persamaan dengan penelitian Tarigan dan Siagian (2015), Anggraeni (2017), dan Putri, et al (2019). Persamaan yang dimiliki yakni menghasilkan media pembelajaran interaktif yang sangat layak untuk digunakan dalam pembelajaran.

Media pembelajaran interaktif berbasis PBL dan permainan ular tangga layak digunakan dalam pembelajaran karena memiliki beberapa kelebihan. Media pembelajaran interaktif berbasis PBL dan permainan ular tangga dapat digunakan di berbagai perangkat yaitu komputer, laptop, dan HP Android. Tampilan layar media bagus dan menarik sehingga memotivasi siswa untuk belajar. Siswa dapat mengulang kembali pembelajaran dalam media pembelajaran dengan mudah. Media pembelajaran interaktif berbasis PBL dan permainan ular tangga dapat melatih keterampilan berpikir dan psikomotorik siswa karena penggunaannya melibatkan aktivitas fisik dan mental siswa. Penggunaan media pembelajaran interaktif berbasis PBL dan permainan ular tangga tidak membutuhkan sambungan internet.

Selain memiliki kelebihan, media pembelajaran berbasis problem based learning dan permainan ular tangga juga memiliki kekurangan. Media pembelajaran hanya berisi satu tema pembelajaran. Permainan ular tangga dalam media pembelajaran ini belum dilengkapi dengan timer untuk mengetahui waktu yang dibutuhkan siswa dalam bermain ular tangga. Media pembelajaran interaktif berbasis PBL dan permainan ular tangga tidak dapat diedit oleh guru.

\section{SIMPULAN}

Berdasarkan hasil penelitian dan pembahasan, maka dapat disimpulkan bahwa Penelitian pengembangan ini menghasilkan media pembelajaran interaktif berbasis Problem Based Learning dan Permainan Ular Tangga berbentuk $C D$ atau soft file dilengkapi dengan buku panduan penggunaan. Penggunaan media ini membantu guru dalam menciptakan lingkungan belajar yang menyenangkan. Siswa lebih senang dalam belajar menggunakan media ini karena media ini memuat video, audio, dan gambar yang memperjelas siswa untuk memahami materi pembelajaran IPS. Siswa juga lebih tertarik untuk mengerjakan soal karena dikemas dalam bentuk permainan. Hasil validasi ahli dan hasil uji coba lapangan terhadap kelayakan media mendapatkan rata-rata persentase sebesar 91,13\% dan 85,17\%. Oleh karena itu, dapat disimpulkan bahwa media pembelajaran interaktif berbasis PBL dan permainan ular tangga terbukti layak digunakan untuk siswa kelas IV SD.

\section{SARAN}

Berdasarkan simpulan yang sudah diuraikan, maka penulis menyarankan penggunaan media pembelajaran interaktif berbasis PBL dan permainan ular tangga agar digunakan seluruh SD di 
tingkat kecamatan. Penulis juga menyarankan agar media pembelajaran ini dikembangkan oleh guru untuk mata pelajaran dan materi pembelajaran lainnya.

\section{DAFTAR PUSTAKA}

Anggraeni, R. (2017). Pengembangan Media Pembelajaran Interaktif Berbasis Model Problem Based Learning (PBL) Menggunakan Indikator Kemampuan Berpikir Kritis Ennis Pada Materi Biologi. (Doctoral dissertation, UIN Raden Intan Lampung).

Budiman, A., Suryana, C., \& Dewi, R. R. (2017). Pengembangan Media Pembelajaran Matematika Berbasis Game Ular Tangga Untuk Sekolah Dasar Kelas Satu. Seminar Nasional Informatika (SNIf), 1(1), 540-545.

Huijser, H., Kek, M. Y., \& Terwijn, R. (2015). Enhancing Inquiry-Based Learning Environments with the Power of Problem-Based Learning to Teach 21st Century Learning and Skills', InquiryBased Learning for Science, Technology, Engineering, and Math (Stem) Programs: A Conceptual and Practical Resource for Educators (Innovations in Higher Education Teaching and Learning, Volume 4, 301-320. doi:10.1108/S2055364120150000004017

Istianah, Y., Wiryokusumo, I., \& Leksono, I. P. (2020). Pengembangan Multimedia Pembelajaran Interaktif Menggunakan Transisi Morph dan Zoom Materi Perbandingan. Jurnal Pendidikan Edutama, 7(2): 113-126.
Khamzawi, S., Wiyono, K., \& Zulherman. (2015). Pengembangan Multimedia Interaktif Berbasis Model Pembelajaran Problem Based Learning pada Mata Pelajaran Fisika Pokok Bahasan Fluida Dinamis Untuk SMA Kelas XI. Jurnal Inovasi dan Pembelajaran Fisika, 2(1), 100108.

Pangestu, R. D., Mayub, A., \& Rohadi, N. (2018). Pengembangan Desain Media Pembelajaran Fisika SMA Berbasis Video pada Materi Gelombang Bunyi. Jurnal Kumparan Fisika, 1 (1), 48-55.

Ramadhani, T., \& Koryati, D. (2015). Analisis Model Dan Media Pembelajaran yang Digunakan oleh Guru pada Mata Pelajaran Ekonomi di SMA Se-Kecamatan Inderalaya. Jurnal PROFIT Kajian Pendidikan Ekonomi dan Ilmu Ekonomi, 2(1), 34-45.

Sani, R. A. (2018). Pembelajaran Saintifik untuk Implementasi Kurikulum 2013. Jakarta: Bumi Aksara.

Sapriya, S. (2009). Pendidikan IPS, Konsep dan Pembelajaran. Bandung: PT Remaja Rosda Karya.

Tarigan, D., \& Siagian, S. (2015). Pengembangan Media Pembelajaran Interaktif Pada Pembelajaran Ekonomi. Jurnal Teknologi Informasi \& Komunikasi dalam Pendidikan, 2(2), 187-200.

Tegeh, M., \& Budiartini, N. K. S. (2017). Pengaruh Model Pembelajaran Question Student Have (Qsh) Berbantuan Permainan Ular Tangga Terhadap Hasil Belajar IPA. International Journal of Elementary Education, 1(2), 137144. 
Veličković, S. (2013). The Game - A Real Chance of Modern Education. International Journal of
Cognitive Research in Science, Engineering and Education, 1 (1), 63-70. 
12 JURNAL PENDIDIKAN EDUTAMA, Vol. 8, No. 1 Januari 2021 